\title{
Depository Designations
}

\author{
Aric Ahrens
}

$\mathbf{T}$ hough the FDLP Modernization Act of 2018 failed to land on the president's desk, the first serious attempt at a legislative solution to the structural hindrances facing the Federal Depository Library Program (FDLP) must be applauded. ${ }^{1}$ In particular, granting the Superintendent of Documents the authority to designate depositories is a vast improvement over the current and ancient Congressional District Model of Depository Allocation. The inadequacies of this well intentioned method of allocating depositories nationwide have been articulated since the nineteenth century.

\section{Antebellum}

The designation of depository libraries by members of Congress dates back to before the Civil War. The initial responsibility for designations, delegated to the Secretary of the Interior, ${ }^{2}$ was shortly thereafter handed to "the representative in Congress from each congressional district." ${ }^{3}$ The limit of designating only one depository per district seems to have been borne out of an act directing that further distribution of documents be "at the instance of representatives from Congress districts in which such public documents have not already been distributed so that the quantity distributed to each congressional district and territory shall be equal." This limitation of one designation per district was also implied in amendments in 1861, which included the earliest mentions of "depositories" and "designations." This amendment was intended to discourage fluidity in depository designations between sessions of Congress, indicating that designations ought to be considered permanent unless the Secretary of the Interior found a depository no longer suitable.

The phrase "certain Public Documents" in the joint resolutions of 1857 and 1858 was replaced by "all Public Documents" in the act of $1859{ }^{6}$ The designation of a depository by a member of Congress provided the Districts' constituents with a comprehensive government documents collection. This was therefore a theoretically effective way of allowing members of Congress to provide access to a full cadre of government information to their constituents. In those districts with established depositories, an effective geographic distribution of government information had been achieved.

\section{Late Nineteenth Century}

Yet, even as early as 1876, the unequal distribution of designated depositories was noted by the government. The Department of the Interior indicated that at that time "one State and three Territories" each had "a greater number of depositories than the aggregate number of Senators, Representatives and Delegates," while the state of Louisiana, entitled to eight designations, had "but one designated depository, namely, the State University at Baton Rouge."

The burden of receiving a comprehensive collection of documents weighed on depositories, which begat the concept of selective depositories, dating back to at least $1891 .^{8} \mathrm{~A}$ report of the American Library Association's (ALA) Government documents committee recommended reforms that would have allowed for the concept of what are now called Regional and Selective depositories. ${ }^{\text {? }}$

The first annual report of the public printer following the adoption of the Printing Act of 1895 indicated it was a "pity" that small school libraries should be "compelled to receive the same embarrassingly large numbers of documents that are sent to the great libraries" and even indicated the use of a stealth selection plan "without any special authority" by "making a supplementary mailing list" for "certain schools" where "only the documents they have especially asked for are sent to the libraries" on the list. ${ }^{10}$

\section{Early Twentieth Century}

At the ALA Conference in 1907, an attendee lamented that, "In some states, there are important libraries which can not become depositories because the places are filled, and there are small libraries which are depositories and where no care is taken of the books." The solution, it was articulated, was "to have the depositories arranged in some rational fashion." 11

The same attendee commented with regards to comprehensive collections that "some arrangement ought to be made 
whereby it shall be possible, that a library can select before the books are sent it the volumes which it wishes." ${ }^{12}$

Comments by the Superintendent of Documents at the same conference described distribution of depositories by congressional district to be due to the "most absurd law that could be possibly conceived of." ${ }^{\text {13 }} \mathrm{He}$ went on to lament that it was "absurd to allow the Government of the United State to be so generous when its generosity is imposing upon the libraries of the country a commodity which they do not want or use"14 and further exclaimed, "please don't blame the Superintendent of documents; we didn't make the law; we are only acting under it." 15

In 1907, Congress took note of the problem that decennial redistricting created by continually increasing the number of Congressional districts, and therefore opportunities for depository designations, and over time larger and larger document distribution. The solution was to grant authority to the Public Printer to increase the volume of documents to be distributed "as the redistricting of States or the rearrangement of depository lists under provisions of law shall demand."

\section{Initial Push for a "Selection Plan"}

William L. Post, Superintendent of Documents, seems to have reversed his position in 1907 that "the oft-suggested method of library selection" involved "too much of the personal equation" as "no one knows what contingency may arise" where a comprehensive collection would be needed. ${ }^{17}$ By 1908 , he argued that "a moment's reflection will show that there should be a certain discretion given which would permit smaller libraries to avail themselves only of the receipt of such publications as they could reasonably care for." ${ }^{18}$ In 1911, the Superintendent of Documents lauded the introduction of S. 2564, which would have accorded to "depositories the privilege of selecting what class of documents they desire." 19

\section{Apportionment Limits Designations}

By tying depository designation to congressional districts the depository system was initially "related, by rough extension, to population." ${ }^{20}$ There was in theory an unlimited number of designations, as there was "no limit on the number of representatives, and it was expected that as population increased and new states were admitted to the Union, more congressional districts would be added." ${ }^{21}$ However, by 1912, the rough relation of depositories to population began to fray, when Congress, ${ }^{22}$ set "a limit of 435 on the number of representatives" and therefore districts, and by extension depository designations. ${ }^{23}$

\section{A Decade of "Selection Plan" Ddvocacy}

In 1912, the Superintendent of Documents indicated that he approved of "sending libraries what they can properly use and what they want," ${ }^{24}$ and in 1915 indicated support for a plan that would offer depositories relief "by granting them the privilege of selection." 25 The Public Printer in 1918 described libraries as demanding "relief from the overcrowded condition of their shelves" ${ }^{26}$ and in 1919 described Government publication "distribution, by law, to depository libraries" as being "unsatisfactory" due to the fact they had to "accept copies of everything of a public nature." ${ }^{27}$ The Superintendent of Documents noted that the "underlying motive which prompted Congress to provide for the establishment of one library in each Congressional district was theoretically good; but time has proved that in a great many districts, libraries can not be found that are in a position to care for the enormous quantity of publications received under such designation" 28 and indicated that the "demand for relief from burdens imposed on [depositories] by being compelled to accept everything printed" continued. ${ }^{29}$ The Public Printer in 1920 supported a "system whereby libraries could in a way make their selection of publications."30

\section{Legislative Efforts in the Teens}

During the teens, there was a legislative effort that, had it been successful, would have granted authority to the Superintendent of Documents to designate depositories, ${ }^{31}$ and one that would have instituted a selection plan. ${ }^{32}$ There was also an effort addressing the Superintendent of Documents' criticism that depository designations could "be changed ... at the commencement of any Congress" causing "broken sets in numerous libraries, instead of fine collections at convenient points for reference use by the public." 33 This resulted in legislation that made depository designations permanent. ${ }^{34}$

\section{Roaring Twenties}

The tone from the Public Printer only grew more terse with the 1920 s, decrying the "avalanche of Government publications" annually descending on depository libraries and noting that only a "few libraries in the larger cities" could house comprehensive collections. ${ }^{35}$ Their complaints finally moved Congress to act in 1922, allowing depositories to select the documents they wished to receive from a list prepared by the Superintendent of Documents. ${ }^{36}$ The Public Printer's initial reaction to the implementation of the plan was positive, and noted that 51 depositories effectively gave up their designations by choosing to select no publications, while only 51 of the 421 depositories chose to select comprehensive collections and nearly 75 percent of depositories chose to select 50 percent or fewer of 
the available publications. ${ }^{37}$ The Congressional District Model of Depository Allocation no longer provided an unlimited geographic distribution of comprehensive collections of government information, but instead a limited geographic distribution of selective collections.

In 1926, the Superintendent of Documents indicated that there was "considerable dissatisfaction expressed ... regarding the law which provides for the allotment of designated depository libraries" and was convinced of a "necessity for congressional action which will result in a more equitable distribution of libraries throughout the States." 38 The Public Printer noted that the then recent change of selecting documents received had revealed that many designations were not selecting "adequate deposits of government publications, thereby making their designation as depositories of little service to the public" ${ }^{39}$ which was seconded by the Superintendent of Documents who declared that a "library that desires only a few publications is not deserving of the privilege of designation as a depository." ${ }^{\prime 40}$

The distribution of depositories by Congressional district and the problem of reapportionment and redistricting was succinctly noted by the Superintendent of Documents in 1926.

With the subsequent growth and shifting of the population and the various changes in the boundaries of congressional districts, many depository libraries are now not located so as to serve the districts for which they were originally designated. But other depository libraries cannot be selected under the present law for the new and large centers of population. For example, there are two depository libraries in a small eastern town while the libraries from two much larger cities in the same district are barred under the present law from designation as depositories for Government publications.

On the other hand, many districts apparently do not desire or can not assume the burden of having a depository for Government publications. ... The ... vacant designations can not, however, be assigned to libraries in other districts. ${ }^{41}$

The Superintendent of Documents, having advocated a legislative fix for depository designations, found a Congressional ally to push for the plan. A bill was introduced by Hiram W. Johnson, Republican of California, ${ }^{42}$ in the Senate on December $22,1926,{ }^{43}$ that would have transferred the responsibility for depository designation to the Superintendent of Documents in partnership with the Librarian of Congress, while limiting the number of depositories at two thousand. ${ }^{44}$ The Superintendent of Documents lamented the lack of action on this plan, noting the "arbitrary designation on geographic lines," and asserting that seventy-five depositories were unanimous in their support of the new plan. ${ }^{45}$ Senator Johnson introduced an alternate version of his bill ${ }^{46}$ on February 1, 1930, ${ }^{47}$ which similarly delegated the responsibility of depository designation to the team of the Superintendent of Documents and the Librarian of Congress, but capped depository designations at one thousand. ${ }^{48}$ In light of the assertion that the selection plan was a least in part a "money-saving 'reform," 49 the capping of total designations can be interpreted as replacing the cap of two Representative designations per district, which provided some sense of predictability for budgeting.

In 1929 the Public Printer noted that "decennial reapportionments of the House of Representatives and consequent changes of congressional district boundaries have sometimes placed more than one depository library in a district" in which case "the original designations" were "permitted to continue, and a newly created district, without a depository may obtain another library designation. ${ }^{50}$

\section{Depression}

The Government Printing Office (GPO) throughout the Depression offered criticism of the allocation of depositories and the unintended consequences of the selectives legislation. ${ }^{51}$ In 1932 it decried that the selection plan enacted in 1922 had "not been as successful as expected" as a number of libraries were "not making adequate selections for depository purposes." 52 The Public Printer lamented in the 1936 annual report that "a number of depository libraries" had "made so few selections that it" was "impossible for them to make public documents very useful in their communities." 53

While offering a prescription in 1937 to "remedy the defects in our depository library legislation," GPO also diagnosed that "the "depository system" operated "on a political and population basis" and gave "no consideration to the location of a library or its ability to make publications available to the public." ${ }^{54}$ In 1938 it was acknowledged that depository law, "fundamentally the same as that enacted in 1895," written for the purpose of "placing Federal public documents in the libraries throughout the United States" had led to "waste on the one hand and unfairness on the other," because the framers of the law could not have foreseen the "development of large metropolitan areas and the unevenness in the development of libraries throughout the United States, which have nullified their original intent." 55

In 1938, the chairman of the ALA Public Documents committee, antecedent to the ALA Government Documents Round 
Table (GODORT), raised an objection to depositories servicing small populations, such as depositories in Hardy, Arkansas and Lakeland, Florida. He similarly indicated that major cities such as Chicago and New York City were overrepresented with comprehensive collections, while some metropolitan locations, such as Little Rock, Arkansas, and Tampa and Miami, Florida were without any depositories at all. ${ }^{56}$

\section{Postwar}

In the 1949 edition of United States Government Publications, Boyd and Rips indicated that the "reapportionment of Representatives to Congress, due to increases in population and the changing Congressional district boundaries, have sometimes placed more than one depository in a district" in which case "the original designation [was] allowed to stand."

The ability and willingness, or lack thereof, of depositories to provide substantial government publication access to their districts was also noted in the 1940s. It was noted that due to the ability to select which documents were received many libraries had "failed to assume their full responsibility as a designated depository and at the same time, retaining the privilege, have deprived other libraries from giving a needed and legally provided service to the public." 58

In the 1950s, two specific examples of potential depository libraries decrying the situation can illustrate the problem. Kent State University, with an enrollment of over 8,000, noted that nearby depository designations were held by colleges with as few as 600 students. ${ }^{59}$ Ball State Teachers College in Muncie, Indiana pointed out that the Muncie Public Library only selected one-third of all depository items available. ${ }^{60}$ Both institutions believed that they would be better suited to be the depository designation for their respective districts.

At a congressional hearing in 1956, Superintendent of Documents Carper W. Buckley admitted that while legislation allowing for depository designations intended the distribution of depositories "be equal" for "each congressional district," the actual reality was that the distribution of depository libraries across congressional districts was "nowhere near equal." Expounding, the Superintendent of Documents blamed in part congressional redistricting for the unequal distribution. ${ }^{61}$ The Superintendent of Documents also expressed his opposition to the manner of the expansion of depository designations then under consideration because he felt that GPO was "under some obligation with regard to the distribution being equal in congressional districts." ${ }^{62}$

\section{Late Twentieth Century}

In the 1960s, the Superintendent of Documents expressed concern that reforms being considered at expanding the number of allowed designations, reforms eventually enacted with the Depository Library Act of 1962, would "open the door" to "a flood of requests from hundreds of libraries and that the addition of any depositories to our present system [was] bound to cost money." ${ }^{\prime 3}$ The Superintendent of Documents' admission that the distribution of depositories among the congressional districts was unequal, and assertion that there would be a high demand for new designations should reforms be enacted, points to the failures of the congressional district model to distribute depositories where they were needed.

The Superintendent of Documents also admitted that "the libraries which have been designated" were "not in all cases the best libraries to serve the needs of the district" but opined that "to tell a library that it was not selecting enough items or that because it had remained a small college since 1895 it no longer deserves consideration as a depository" would not be a view likely to be shared by the depository receiving the criticism. ${ }^{64}$

A concise description of the period between the establishment of the selection plan in 1922 and the passage of the Depository Library Act of 1962 noted that during those four decades, "most depositories had become so overly selective that access to a full file of government publications [was] increasingly difficult." ${ }^{35}$

During the debate over H.R. 8141 (which, amended, became the Depository Library Act of 1962) in spring 1962, Clifton Brock indicated that to "depart altogether from the congressional-designation method" would be an "ideal approach," but that "considerations of time and politics" made that result unlikely. His main concern seems to have been that having passed the House, major changes ought not be proposed in the Senate, advising that it was "wise to make the amendment as simple and attractive to the Senate as possible." A recommendation to amend the bill to include additional Senatorial designations, at the rate of one new depository for every million population, was proposed. These additional Senatorial designations would have helped ameliorate the congressional district model's deficiencies. ${ }^{66}$

The Depository Library Act of 1962 accomplished two changes that helped mitigate but not fully remedy the conflicts. Regional Depositories were intended to restore the geographically distributed comprehensive collections that had been lost when Selective Depositories were introduced. The second provision was a doubling of the number of Representative depository designations to two per district. But even after the change, there were nineteen schools and universities with more than 
five thousand students that were seeking but unable to obtain depository status, ${ }^{67}$ due to the fact that the designations in their Congressional districts had already been allotted and the Senatorial designations were given to other institutions. ${ }^{68}$ The majority of these schools and universities were located in "large metropolitan areas where the needs for immediate access to all the increasing variety of information in government publications [were] the greatest." ${ }^{, 69}$

By the mid 1970s, the FDLP was "again faced with the problem of only a few depository designations remaining in the areas where they will be utilized," and there were even multiple legislative efforts to extend the limit on Congressionally designated depositories to three per district. ${ }^{70}$ The library community recommended at this time that the geographic distribution of depository designations by Congressional district be augmented with designations "based on each library's demonstrated need and ability to meet national depository standards." ${ }^{71}$

\section{Twenty-First Century}

By the early twenty first century, ninety-nine districts had more Representative designated depositories than would be allowed by law, typically in urban areas of states having over time lost population on a relative basis, such as in the Rust Belt. Meanwhile, fifty-eight districts were devoid of Representative designated depositories, typically in states whose population as a proportion of the nation were increasing, and with it their representation in Congress, such as California. ${ }^{72}$

Additionally, libraries were relinquishing depository status at an alarming rate, and fewer libraries were choosing to become depositories, yielding the first downward trend in the number of depositories in the program's history. An academic survey of libraries having left the Federal Depository Library Program cited staff, funding issues, and space concerns as impacting their decision to leave the program. ${ }^{73}$

The survey also revealed that the availability of government information on the internet called into question the value of depository status. ${ }^{74}$ At a time when libraries were reluctant to take on the responsibilities of participation in the Federal Depository Library Program, it seemed arbitrary to deny a library that would be able to largely provide service nationwide via electronic resources the opportunity to assume depository status solely based on the fact that the library was currently located in a district with two or more Representative depositories.

While discussion of electronic-only depositories was widespread around the turn of the century as a way to stem the tide of defections from the program and as a way to increase future participation, the path to an effective electronic-only depository cleared a full decade later when the GPO amended the Legal Requirements and Program Regulations to eliminate the requirement to select certain tangible item numbers, the obstacle that was preventing the creation of electronic depository libraries. ${ }^{75}$

\section{Contemporary Concerns}

The drawbacks of the Congressional District Model of Depository Allocation are still relevant today. In 2008, it was noted that some libraries that originally received their designations by members of Congress had requested changes in their status to a "by law" designation as are afforded libraries in special categories such as law school libraries and land-grant college libraries. These requests were made "to create an opportunity for another library to receive the congressional designation." ${ }^{76}$

In 2014, Sitting Bull College Library received the first digital-only depository designation as a Land Grant college. ${ }^{77}$ The following year, 2015, the Richardson Library of DePaul University was designated as the first digital-only Representative designated depository, in Illinois' fifth Congressional District. ${ }^{78}$ Had the current district boundaries been drawn differently, the four preexisting Representative depositories in the fifth and ninth districts could have been evenly split between them, which would have precluded DePaul's designation.

An extremely recent example further demonstrates that the inadequacies are still affecting depository designations. In late 2018, the depository at Western Illinois University yielded their Senatorial designation in lieu of a Representative designation, in order to facilitate the designation of Dixon Public Library using their yielded at-large Senatorial designation. ${ }^{79}$

\section{Moving Forward}

The FDLP Modernization Act of 2018, introduced by Rep. Gregg Harper of Mississippi, would have addressed the changed landscape with regards to depository allocation. ${ }^{80}$ The Act would have granted discretion to the Superintendent of Documents to designate Federal Depository Libraries, which would be de facto digital-only depositories. Only by seeking the additional designation as a Selective Depository would a library be granted the privilege of receiving tangible documents. The per district cap is removed, and only a recommendation by a member of Congress would be required for the additional designation. From the text of the bill, the process of designating Selective Depositories shall yield

an adequate number and distribution of Selective Depository Libraries in order to meet the information needs of the public, and shall not prevent the 


\section{Ahrens}

designation of at least one Selective Depository Library in each congressional district. (emphasis added)

Therefore, the driving force behind the designation of even Selective Depositories with tangible holdings is based on the needs of the public rather than the need for an "empty slot." Additionally an avenue is created for future Selective Depositories, whereby a library can "try on for size" their digitalonly Federal Depository Library status before committing to upgrade their status to tangible receipts and Selective status.

By granting discretion for depository designation to the Superintendent of Documents and changing the default designation from a Selective Depository with tangible receipts to a digital-only Federal Depository, the FDLP Modernization Act of 2018 would have belatedly and blessedly brought depository allocation into the twenty-first century. Hopefully, this language will be revisited in the 116th Congress. By removing the expectation of physical holdings and the barrier of open designation "slots" the Federal Depository Library Program would lay the groundwork for possible growth in program participation after decades of attrition.

Aric Ahrens (ahrens@iit.edu), Engineering and Government Information Librarian, Paul V. Galvin Library, Illinois Institute of Technology.

\section{References and Notes}

1. The FDLP Modernization Act of 2018, H.R. 5305, 115th Cong. (2018).

2. A Resolution Respecting the Distribution of Certain Public Documents, 11 Stat. 253 (1857).

3. Joint Resolution Respecting the Distribution of Certain Public Documents, 11 Stat. 368 (1858).

4. An Act Providing for Keeping and Distributing All Public Documents, 11 Stat. 380 (1859).

5. An Act to Amend an Act Approved February Fifth, One Thousand Eight Hundred and Fifty-Nine, Entitled "An Act Providing for Keeping and Distributing All Public Documents, and for Other Purposes,"12 Stat. 244 (1861).

6. An Act Providing for Keeping and Distributing All Public Documents, (1859) 11 Stat. 380 (1859).

7. Department of the Interior, Bureau of Education, Public Libraries in the United States of America: Their History, Condition, and Management (1876): 283.
8. Judith Gecas, The Depository Library Act of 1962: A Legislative History and Survey of Implementation, (March 1975): 8 .

9. R. R. Bowker, "Discussion," Bulletin of the American Library Association 1 (July 1907): 142.

10. GPO, Annual Report of the Public Printer for the Fiscal Year Ended June 30, 1895, 20, SuDoc no: GP 1.1:895.

11. Steiner, "Discussion," Bulletin of the American Library Association 1 (July 1907): 139.

12. Steiner, 140.

13. William L. Post, "Address of Mr. Post," Bulletin of the American Library Association 1 (July 1907): 136.

14. Post, 137.

15. Post, 138.

16. An Act to Amend an Act Providing for the Public Printing and Binding and the Distribution of Public Documents, 34 Stat. 1014 (1907).

17. GPO, Annual Report of the Public Printer for the Fiscal Year Ended June 30, 1907, 353, SuDoc no: GP 1.1:907.

18. GPO, Annual Report of the Public Printer for the Fiscal Year Ended June 30, 1908, 402, SuDoc no. GP 1.1:908.

19. GPO, Annual Report of the Public Printer for the Fiscal Year Ended June 30, 1911, 376, SuDoc no. GP 1.1:911.

20. Clifton Brock, "The Federal Depository Library System: A Proposal for Change," College and Research Libraries, 23 (May 1962): 198.

21. Brock, 197.

22. An Act for the Apportionment of Representatives in Congress among the Several States under the Thirteenth Census, 37 Stat.13 (1911).

23. Brock, 198.

24. GPO, Annual Report of the Public Printer for the Fiscal Year Ended June 30, 1912, 410, SuDoc no. GP 1.1:912.

25. GPO, Annual Report of the Public Printer for the Fiscal Year Ended June 30, 1915, 387, SuDoc no. GP 1.1:915.

26. GPO, Annual Report of the Public Printer for the Fiscal Year Ended June 30, 1918, 18, SuDoc no. GP 1.1:918.

27. GPO, Annual Report of the Public Printer for the Fiscal Year Ended June 30, 1919, 17, SuDoc no. GP 1.1:919.

28. Ibid., 418.

29. Ibid., 411.

30. GPO, Annual Report of the Public Printer for the Fiscal Year Ended June 30, 1920, 13, SuDoc no. GP 1.1:920.

31. United States House of Representatives, Revision of Printing Laws, 64th Congress, 1st Sess. (1916): 123 H. Rept. 64-32. 
32. United State House of Representatives, Revision of Printing Laws, 63rd Congress, 2nd Sess. (1914): 71 H. Rept. 63-564.

33. GPO, Thirteenth Annual Report of the Superintendent of Documents for the Fiscal Year Ended June Thirty, 1907, 40-41, SuDoc no. GP 3.1:907.

34. An Act Making Appropriations for Sundry Civil Expenses of the Government for the Fiscal Year Ending June Thirtieth, Nineteen Hundred and Fourteen, and for Other Purposes, 38 Stat. 75 (1913).

35. GPO, Annual Report of the Public Printer for the Fiscal Year Ended June 30, 1921, 37, SuDoc no. GP 1.1:921.

36. An Act Making Appropriations for the Legislative Branch of the Government for the Fiscal Year Ending June 30, 1923, and for Other Purposes, 42 Stat. 436 (1922).

37. GPO, Annual Report of the Public Printer, 1923, 13, SuDoc no. GP 1.1:923.

38. GPO, Annual Report of the Public Printer, 1926, 102, SuDoc no. GP 1.1:926.

39. Ibid., 23.

40. Ibid., 102.

41. Ibid., 23.

42. A Bill to Authorize the Designation of Depositories for Public Documents, and for Other Purposes, S. 4973, 69th Cong. (1926).

43. "Bills Introduced," 69th Congress 2nd Sess., 68 Congressional Record 910 (1926).

44. "Public Documents Depositories," Library Journal 52, no. 4 (February 15, 1927): 197.

45. GPO, Annual Report of the Public Printer, 1927, 103, SuDoc no. GP 1.1:927.

46. A Bill to Authorize the Designation of Depositories for Public Documents, and for Other Purposes, S. 3402. (1930) 71st Cong.

47. "Bills Introduced," 71st Congress, 2nd Sess., 72 Congressional Record 2812 (1930).

48. "Three Recent Bills Before Congress," Library Journal, 55, no. 5 (March 1, 1930): 227.

49. Gecas, 9.

50. GPO, Annual Report of the Public Printer, 1929, 38, SuDoc no. GP 1.1:929.

51. The Government Publishing Office was originally established as the Government Printing Office, beginning operation on March 4, 1860. Congress redesignated GPO as the Government Publishing Office on December 17, 2014, https://www.gpo.gov/who-we-are/our-agency/history.

52. GPO, Annual Report of the Public Printer, 1932, 90, SuDoc no. GP 1.1:932.
53. GPO, Annual Report of the Public Printer, 1936, 64, SuDoc no. GP 1.1:936.

54. GPO, Annual Report of the Public Printer, 1937, 64, SuDoc no. GP 1.1:937.

55. GPO, Annual Report of the Public Printer, 1938, 111, SuDoc no. GP 1.1:938.

56. J. K. Wilcox, "Proposed Survey of Federal Depository Libraries," Public Documents 1938 (1938): 31.

57. Ann M. Boyd and Rae E. Rips, United States Government Publications (New York: H. H. Williams, 1949): 30.

58. Boyd and Rips, 31.

59. Gecas, 8.

60. Committee on House Administration, Revision of Depository Library Laws: Hearings Before a Subcommittee of the Committee on House Administration, House of Representatives, Eighty-Fifth Congress, First Session, Pursuant to $H$. Res. 128, a Resolution Authorizing a Full Study of Federally Operated Printing Services and Government Paperwork in General. October 7, 10, 14, and 17, 1957 (on H.R. 9186); June 19, 1958 (on H.R. 11042). 85th Congress, 1st Sess. (1958): 138-39.

61. Committee on House Administration, Sale and Distribution of Government Publications by the Superintendent of Documents. Hearing Before a Subcommittee of the Committee on House Administration, House of Representatives, Eighty-Fourth Congress, Second Session, Pursuant to H. Res. 262, August 7, 1956., 84th Congress, 2nd Sess. (1956): 4.

62. Ibid., 5 .

63. Ibid., 9.

64. Ibid., 9.

65. Gecas, 41.

66. Brock, 248.

67. Brock, 206.

68. Gecas, 25.

69. Gecas, 25.

70. Gecas, 26.

71. ALA Ad Hoc Committee on the Depository Library System, "Report of the Ad Hoc Committee on the Depository Library System," DttP: Documents to the People 3, no.2 (November 1974): 15.

72. Aric G. Ahrens and Luke A. Griffin, "Gerry-Meandering: An Assessment of the Congressional District Model of Depository Allocation," DttP: Documents to the People 31, no. 3-4 (Fall/Winter 2003): 22.

73. Luke A. Griffin and Aric G. Ahrens, "Easy Access, Early Exit? The Internet and the FDLP," DttP: Documents to the People 32, no. 3 (Fall 2004): 38.

74. Griffin and Ahrens, "Easy Access," 38. 
75. Federal Depository Library Program, "Item Numbers 0556-C and 1004-E Are Not Required for Selective Libraries," News \& Events, August 26, 2014 https:// www.fdlp.gov/news-and-events/2037-item-numbers -0556-c-and-1004-e-are-not-required-for-selective -libraries.

76. Suzanne Sears, "Connecting Constituents to Government Information: 150 Years of Congressionally Designated Libraries," DttP: Documents to the People 36, no. 3 (Fall 2008): 18.

77. Federal Depository Library Program, "Joining the FDLP: Sitting Bull College Library's Experience," Community Insights, November 5, 2014 https://www.fdlp.gov/all -newsletters/community-insights/2106-joining-the-fdlp -sitting-bull-college-library-s-experience.

78. Federal Depository Library Program, "Chicago Library Joins GPO Program That Provides Access to Government Information," News \& Insights, May 6, 2015 https:// www.fdlp.gov/news-and-events/2274-chicago-library -joins-gpo-program-that-provides-access-to-government -information.

79. Charles Malone, email communication, November 7 , 2018.

80. The FDLP Modernization Act of 2018, H.R. 5305, 115th Cong. (2018). 